\title{
Miroslav Kouřil a jeho cesta ke strukturalismu jako metodě i programu ${ }^{1}$
}

\author{
Šárka Havlíčková Kysová
}

Teoretickým otázkám scénografie či vizuální stránky inscenace z perspektivy českého divadelního strukturalismu se zřejmě nejvíce, systematicky a programově věnoval Miroslav Kouřil (1911-1984). Rozdělovat profesní život na předválečné a poválečné období v případě Kouřila neznamená vytvářet pouze formální a samoúčelný předěl, nýbrž výstižně odlišit dva zásadní směry jeho kariéry v oblasti divadla.

Tato studie si klade za cíl pojednat o poválečném působení významného českého scénografa, který je ponejvíce spojován s českým avantgardním divadlem mezi dvěma světovými válkami a hlavně s theatergraphem. ${ }^{2} \mathrm{~V}$ období po 2 . světové válce se totiž Miroslav Kouřil stal významným činitelem v oblasti divadelního života, ačkoliv jeho vlastní umělecké aktivity a ambice ustoupily do pozadí. Jeho poválečná kariéra se ubírala především k vytváření institucionálního zázemí praktické i teoretické scénografie. Stal se do značné míry jejich hlavním organizátorem a zastával v jejich rámci významné postavení, což vzhledem k období, v němž působil, s sebou nutně muselo nést politicky komplikované kroky, které dodnes vzbuzují řadu otázek. Proto bývá význam působení této osobnosti v kontextu českého kulturněpolitického vývoje ve druhé polovině 20. století obecně vnímán spíše ambivalentně.

Studie je kromě sekundárních zdrojů založena na výzkumu pramenného materiálu v Památníku národního písemnictví, kde je uložena doposud nezpracovaná pozůstalost Miroslava Kouřila. ${ }^{3}$ Další materiály, zahrnující především dokumenty Scénografického

1 Studie je výstupem z GAČR GAP409/11/1082 a částečně shrnuje a rozvíjí poznatky publikované ve studiích a konferenčních příspěvcích, které autorka sama či ve spolupráci s Barborou Příhodovou přednesla či publikovala převážně na zahraničních odborných fórech - viz např. (HAVLÍČKOVÁ KYSOVÁ 2011), (HAVLÍČKOVÁ KYSOVÁ a DIEGO RIVERA PŘíHODOVÁ 2013, 2014).

2 Více o této problematice viz např. (SRBA 1971) nebo (SRBA 2006), viz též (SPURNÁ 2004: 272-273).

3 Autorka této studie prozkoumala v pozůstalosti uložené materiály včetně Kouřilových teoretických spisů, kterým věnovala největší pozornost a na jejichž obsah opakovaně odkazuje v této studii. Závěry vyvozené z tohoto výzkumu materiálu nelze však bohužel vždy demonstrovat na konkrétních př́ikladech otištěných v rámci studie, nebot zde není prostor publikovat rozsáhlé pasáže Kouřilových textů, které by pouze ve větších celcích 
ústavu, včetně podrobných popisů jeho úkolů či systematického rozvoje, jsou k dispozici v Národním archivu v Praze na Chodovci. ${ }^{4}$

\section{Dvě fáze kariéry Miroslava Kouřila}

Vzděláním inženýr architekt Miroslav Kouřil (1911-1984) spolupracoval s Emilem Františkem Burianem v Divadle D. Původně byl jedním z Burianových spolupracovníků v oblasti scénografie vedle Jiřího Novotného, Josefa Rabana, Cesara Grimmicha a Karla Poličanského. Velmi kreativní spolupráce se vyvinula právě v onen vysoce oceňovaný scénický prostředek, „světelný systém“ zvaný theatergraph. Theatergraph kombinoval jevištní akci filmového herce s filmovou či fotografickou projekcí, aby bylo možno specificky esteticky působivým stylem vyjádřit vnitřní pocity a myšlenky dramatických postav. Statická i filmová projekce byly do režijně-scénografické koncepce včleněny dramaticky a souvisle, neměly jen dotvářet či zvýrazňovat básnické dílo. Byly nositelem významu (GROSSMAN 1959: 420). Šlo o nástroj umožňující rozšiřit výrazové prostředky, zejména vizuální metafory, a posílit lyrickou stránku scény či celého představení. Burian tento inovativní a účinný scénický prostředek vyvíjel ponejvíce ve spolupráci s Miroslavem Kouřilem, který byl schopen precizně propracovat i jeho technickou stránku včetně provedení.

Je třeba si uvědomit, že Burianovo Déčko bylo nejen divadlem, ale i kulturní institucí, která plnila řadu dalších funkcí - např́íklad společenskou a vzdělávací. ${ }^{5}$ Již v tomto prostředí se pravděpodobně začala formovat Kouřilova koncepce scénografie i teoretické scénografie, kterou systematicky rozvíjel především v době po druhé světové válce.

V poválečném období se Miroslav Kouřil značnou měrou zasadil o reorganizaci československého divadelního života, když se podílel na centralizaci divadelnictví organizované státem. Jeho kariéra v poválečném, nově politicky formovaném socialistickém Československu zaznamenala poměrně strmý vzestup. V roce 1952 však musel odstoupit z postu náměstka ministra informací a osvěty v kulturně osvětovém odboru (RAUCHOVÁ 2011: 165). Několik let se držel stranou kulturního i politického života. V druhé polovině padesátých let se začal znovu prosazovat v oblasti divadla. Tentokrát především jako teoretik divadla, jehož hlavní zájem tkvěl ve scénografii. $\mathrm{S}$ jeho teoretickou činností bylo úzce spjato úsilí o systematickou reflexi scénografie na institucionální úrovni. Zřejmě nejvíce se tato snaha odrazila v založení Scénografické laboratoře a později Scénografického ústavu, jakož i v několika ambiciózních projektech těchto institucí, o nichž pojednáme.

mohly posloužit jako důkaz autorčina tvrzení. $\mathrm{V}$ případě, kdy rozsah části autorkou diskutovaného Kouřilova textu výrazně nepřesahuje možný prostor pro citované texty, který poskytuje formát časopisecké studie, je autorčino tvrzení samozřejmě řádně podpořeno doslovnou citací či parafrází Kouřilových slov.

4 Na širším výzkumu Kouřilovy pozůstalosti se v jeho různých fázích podílel kromě Barbory Př́íhodové také Martin Bernátek. Později byli zapojeni i studenti Katedry divadelních studií FF MU v Brně, některé další poznatky zpracovává studie Kateřiny Lukáčové publikovaná rovněž v tomto čísle (LUKÁČOVÁ 2016: 159-180).

V Divadle $\mathrm{D}$ se konaly rovněž odborné přednášky. 


\section{Scénografický ústav, Prolegomena Scénografické encyklopedie a Základy teoretické scénografie}

Důležitým obdobím pro sledování a reflexi Kouřilovy teoretické a organizační práce v oblasti scénografie je jeho působení ve Scénografické laboratoři a Scénografickém ústavu, tj. léta 1957-1974. Poměrně rozsáhlá pozůstalost Miroslava Kouřila, čítající 75 kartonů, obsahuje značné množství teoretických či historiografických prací o divadle či přímo o scénografii. Práce historiografické jsou spíše kompilačního rázu, práce teoretické obsahují řadu Kouřilových úvah a analýz, často využívajících strukturalistickou metodu či alespoň její terminologický aparát. V pozůstalosti jsou uloženy dokumenty z Kouřilova pracovního i osobního života. Osobní materiály zahrnují diplomy, osvědčení, legitimace atd. V několika kartonech (č. 6-9) je uložena korespondence, jež byla dle zákona nepřístupná až do roku 2014. Největší část pozůstalosti však zahrnuje Kouřilovy pracovní materiály, které sestávají z jeho architektonických projektů, podkladů pro jeho pedagogickou činnost, poznámek, náčrtů, synopsí knih či přednášek atd.

Svou teoretickou reflexi divadla, a hlavně scénografie, sice Miroslav Kouřil rozvíjel až v období po druhé světové válce, ale činil tak mnohdy v návaznosti na meziválečnou avantgardu a své působení v Burianově Divadle $\mathrm{D}$, v jehož rámci byl dokonce plánován - bohužel nikdy plně nerealizovaný - projekt praktického a teoretického výzkumu scénografie (HILMERA 1962: 21). Po válce se Miroslav Kouřil systematicky snažil vytvářet platformy pro rozvoj teoretických úvah o divadle a posunovat hranice soudobé praktické scénografie. Stál u zrodu Scénografické laboratoře, která nejprve spadala do správy Národního divadla. V roce 1963 došlo k její přeměně v samostatnou instituci nazvanou Scénografický ústav. V době fungování Scénografického ústavu, tj. v letech 1963-1974, stál Kouřil v jeho čele. Po zrušení Scénografického ústavu přešla část jeho agendy do správy Divadelního ústavu v Praze (GABRIELOVÁ 2007: 32).

Původním posláním nově vzniklé Scénografické laboratoře bylo reagovat na aktuální tvưrčí činnost již renomovaných režisérů a scénografů, jako byli Alfréd Radok, Otomar Krejča, Jaromír Pleskot a samožrejmě Josef Svoboda, a na jejich mezinárodní úspěchy. Nově vznikající jevištní formy, jež tito umělci vytvářeli, pracovaly inovativně s pohybem, prostorem a světlem. Žádaly si proto i nové teoretické reflexe. U počátku Scénografické laboratoře tak stála potřeba dokumentovat, analyzovat a teoreticky reflektovat nové scénografické trendy a počiny. Dalším pádným důvodem pro založení Scénografické laboratoře byl současný technický stav českých divadel i samotné technologické podmínky, v nichž inscenace vznikaly. Tyto podmínky byly vnímány jako nedostačující pro potřeby moderní inscenační, a zejména scénografické tvorby (KOLAŘÍK 1967: 1). Miroslav Kouřil se snažil se svými spolupracovníky vytvářet ve Scénografické laboratoři zázemí pro experimentaci v oblasti scénografie. Od počátku v ní byla scénografie považována současně za uměleckou, vědeckou i technickou disciplínu, jež zahrnuje oblast vizuálního umění, jevištní technologie a divadelního prostoru. V rámci Scénografické laboratoře byl odborně zkoumán např. technický rozvoj divadelních budov a technologií, byly pořádány semináře a workshopy zaměřené na 
různé dílčí disciplíny praktické scénografie, které měly za cíl vychovat odborníky v oblasti jevištního výtvarnictví, např́íklad maskéry, osvětlovače, jevištní výtvarníky atd.

V roce 1963 se ambice Kouřilova týmu rozšírily za hranice původní víceméně experimentální práce v oblasti scénografie a jevištní technologie. Nově založený Scénografický ústav se stal pod Kouřilovým vedením „resortním vývojovým ústavem ministerstva školství a kultury pro technický rozvoj divadelních, kulturních a osvětových zařízení, s celostátní působností, a také oborovým střediskem vědeckých a technickoekonomických informací a střediskem patentovým a normalizačním“ (KOLAŘíK 1967: 2). Právě v tomto období začal být $\mathrm{v}$ práci Scénografického ústavu obecně kladen velký důraz na teoretickou stránku scénografie. Byly definovány čtyři hlavní oblasti zájmu, z nichž první se zaměřovala na řešení technických, technologických a některých ekonomických problémů kulturních a osvětových zařízení, přičemž byl zdůrazňován vědecký základ jejich řešení. Druhá oblast se soustř̌edila na „umělecko-technické problémy scénického výtvarnictví a problémy scénografie jako vědeckotechnického oboru“. Třetí se zabývala vývojem divadelních prostorů a zpracováváním (po stránce technického zařízení) projektů divadel i kulturních a osvětových zařízení. Mělo tak být činěno ve spolupráci s jednotlivými rezortními specializovanými útvary. Čtvrtá, poslední oblast zájmu se zaměřovala na zpracovávání projektů a řešení technického rozvoje zařízení, jako byly např. scény kulturních domů, cirkusů, prostředků technické zábavy, výstavnictví a expozičních technik (KOLAŘíK 1967: 2).

Organizační struktura Scénografického ústavu byla poměrně složitá a výrazně hierarchizovaná. Dělila se na několik oddělení, pracovních skupin a dalších podskupin. Mnohdy protichůdné informace, které nacházíme v archivních materiálech, znemožňují její přesný popis i charakteristiku její proměny v průběhu let. Můžeme však říci, že různé výzkumné úkoly, jimiž se pracovníci Ústavu zabývali, zahrnují zkoumání jak praktických disciplín (práci se světlem či jevištní technologii), tak i oblasti spíše teoretického rázu - psychologii scénografie, fyziologii a pracovní lékařství a dějiny a teorii scénografie (KOLAŘíK 1967: 2). Jednotlivé úkoly každé ze skupin byly velmi přesně definovány a dokumentovány. ${ }^{6}$

Scénografický ústav byl institucí podporovanou (ze čtyřiceti procent jejího rozpočtu) státem. Zbylých šedesát procent objemu financí si musel zajistit sám vlastní činností (KOUŘIL 1972: 65). Provozoval vlastní knihovnu, archiv a realizoval řadu vydavatelských počinů. Zřejmě nejznámějším z nich se stala Knihovna divadelního prostoru, edice, v níž již ve čtyřicátých letech vyšly kromě jiného v českém překladu Jaroslava Pokorného Prospectiva Josefa Furtenbacha (1944) a Vitruviovy a Polluxovy úvahy o divadelní architektuře, opatřené předmluvou Miroslava Kouřila (1944). ${ }^{7}$

Scénografický ústav během své existence vytvořil několik publikačních platforem, které se zaměřovaly především na otázky scénografie - teorie i praxe. Zejména periodikum,

6 Úkolům Scénografického ústavu se podrobněji věnuje studie Kateřiny Lukáčové (LUKÁČOVÁ 2016: 159-180).

7 Jako nakladatel je však u obou titulů uveden Ústav pro učebné pomůcky průmyslových a odborných škol. Náklad činil v obou případech 3000 kusů. 
označované zpravidla jako sborník, Acta scaenographica dávalo kromě jiného značný prostor analytickým a kritickým textům zaměřeným na scénografii. Dnes nám často poskytuje cenné zdroje informací o zásadních inscenacích. Od roku 1964 byly také vydávány Informačni listy o scénické technice (KOLǍ̌ÍK 1967: 3) a samozřejmě nelze zapomenout na Interscenu, charakterizovanou jako „teoretický a uměleckotechnický časopis Scénografického ústavu v Praze“.

Dalším a v historii československé divadelní vědy ojedinělým počinem byla Prolegomena Scénografické encyklopedie. Tento celkem dvacetidílný soubor, jehož jednotlivé svazky obsahovaly řadu teoretických či historiografických textů zaměřených nejen na scénografii, ale rovněž na dějiny divadelních kultur a na inscenační praxi obecně, vycházel v první polovině sedmdesátých let (1970-1973) v rámci př́ípravy bohužel nerealizovaného projektu Scénografické encyklopedie. Na stránkách Prolegomen i ostatních publikačních platforem zveřejňovali své texty přední českoslovenští odborníci. Rovněž nebylo výjimkou zveřejnění významné stati zahraničního odborníka v českém překladu.

Ambiciózní ediční činnost, vydávání odborných periodik a rovněž náročný projekt přípravy Scénografické encyklopedie byly počiny, na nichž se zpravidla autorsky či organizačně podílelo více osob a obvykle pod vedením či dohledem Miroslava Kouřila coby šéfa instituce. Kouřil sám však byl autorem řady převážně teoretických či historickoteoretických prací o divadle či př́imo scénografii. Řadu z nich vytvořil ještě před svým nástupem do vedení Scénografického ústavu i dávno před samotným vznikem instituce. Například v roce 1945 vydává svoji studii Divadelni prostor, o deset let později (1955) vychází jeho práce $O$ malém jevišti. Později, a to i v období, kdy se Kouřil věnoval vedení Scénografického ústavu, vzniklo několik dalších prací, z nichž mnohé zůstaly pouze v rukopise. V Kouřilově pozůstalosti lze najít rukopisy či strojopisy připravovaných publikací, některé z nich dokonce v různých verzích. Kromě poněkud kuriózně vyhlížejícího, nikdy nevydaného spisku Slabikář scénografa či rovněž nepublikované Malé učebnice scénografie stojí za pozornost Základy teoretické scénografie, jež lze opět označit za velmi ambiciózně působící projekt. Mělo jít o šestidílnou publikaci zevrubně pojednávající o různých stránkách a otázkách scénografie. Vyšel pouze její první díl, v němž je kromě jiného uveden seznam dalších částí chystaných k vydání. Strojopisy tří dalších částí (II., III. a IV.), některé dokonce v různých variantách, a část čtyři dále rozvrženou do dvou dílů, nalezneme rovněž v Kouřilově pozůstalosti. Kouřilova úvodní, jediná vydaná kniha $(1970 b)^{8}$ z této plánované série vypovídá o velkolepé koncepci. Základy teoretické scénografie měly obsahovat svazky: 1) Úvodní úvahy; 2) Divadelní inscenace; 3) Scénografie; 4) Divadelní prostor; 5) Divadelní experimentace; 6) Aplikace scénografie. Dostupné části tohoto díla (včetně té publikované) pojednávají o scénografii jako o teoretické disciplíně ve velmi široce uchopeném kontextu dějin divadla, např. včetně dílčích pasáží o asijských divadelních kulturách a typech divadelního prostoru, jež užívají. Informace tohoto druhu jsou však v Kouřilově textu často pouze povšechné, mnohdy až zjednodušující, a často dokonce postrádají jasnost sdělení, respektive není zřejmé, jak mají z hlediska argumentační logiky podpořit autorovo pojetí teoretické scénografie. I kom- 
pilační pasáže vykládající vývoj scénografie v kontextu dějin divadla (například první část třetího dílu značená jako „A“) postrádají jasnou koncepci a sdělení, což lze ovšem přikládat skutečnosti, že jde pouze o rukopis, navíc pravděpodobně nedopracovaný.

Některé další Kouřilovy teoretické práce, které mimochodem také najdeme v jeho pozůstalosti, se dočkaly publikování na začátku osmdesátých let - Úvod do vědy o scénických uměnich (1982) či Teorie scénických uměni I (1981) a Teorie scénických umèni II (1982).

Kolektivní díla, vydaná péči Scénografického ústavu, i samotné Kouřilovy práce jsou v souladu s oficiálně proklamovanou snahou Scénografického ústavu hájit scénografii jako vědeckou disciplínu. Tyto snahy, obsahující např. rozsáhlou odbornou diskuzi nad definicí scénografie jakožto (vědecké) disciplíny a následné prosazování této definice Scénografickým ústavem, lze spojovat právě především s prací a ambicemi v oblasti Kouřilova teoretického uvažování o divadle. Specifické pojetí scénografie a s ním související následný požadavek etablování scénografie jako vědecké disciplíny lze totiž sledovat jak v Kouřilově raném teoretickém díle, tak v jeho pracích pozdějších (zejména v 60. letech, kdy již pravděpodobně vznikaly Základy teoretickéscénografie). Kouřilovy pozdější texty však nelze vnímat pouze jako jeho individuální teoretický počin. Kouřilovo uvažování je velmi úzce spjato s jeho působením ve vedení Scénografického ústavu, jehož činnost výrazně ovlivňoval nejen po organizační stránce, ale rovněž v oblasti jeho odborného směřování. Důkazem toho může být právě široký prostor pro diskuzi o povaze scénografie, včetně metodologických východisek či jejího postavení v rámci divadelní vědy a historie divadla, jenž byl těmto tématům poskytnut na stránkách Prolegomen. Zvláštní otázkou v tomto kontextu zůstává v Prolegomenech proklamovaná strukturalistická metoda, jež má tvořit metodologické východisko práce na budoucí Scénografické encyklopedii. ${ }^{9} \mathrm{~V}$ Prolegomenech se skutečně nezř́ídka objevila stat̉ některého ze strukturalistů (např. Jana Mukařovského či ze zahraničních autorů Tadeusze Kowzana atd.). Jakou cestou však Miroslav Kouřil sám dospěl k tomuto strukturalistickému programu Prolegomen a šířeji k uvažování o scénografii? Jaké povahy je Kouřilovo pojetí strukturalistického př́stupu ke scénografii? A jaké důsledky z toho plynou pro definici scénografie a její vnímání jako vědecké disciplíny?

Definice scénografie, jak ji za Kouřilova vedení prosazoval Scénografický ústav, byla nastíněna již ve spise $O$ malém jevišti (1955). Kouřil ji nadále rozpracovával v dalších dílčích pracích (většinou ožrejmujících práci Scénografické laboratoře), avšak její komplexnější chápání najdeme až v Prolegomenech (zejména v prvním díle) a v Základech teoretické scénografie.

Pojmem scénografie tedy Kouřil mínil disciplínu, která se skládá z několika disciplín dílčích - jsou to: „scénografie - komplexní disciplína zahrnující výtvarnou práci, technickou nauku a vědu o vytváření a realizaci scénické výpravy; výtvarná scénografie obor výtvarné práce z oblasti užitého výtvarného umění; technická scénografie - nauka o aplikaci technických věd v oblasti scénických umění; teoretická scénografie - věda

$9 \quad$ O záměru opírat práci na Prolegomenech, respektive na Scénografické encyklopedii, o strukturalistický př́istup pojednává Kouřilova spolupracovnice Jarmila Lormanová v př́loze (dodatku) k prvnímu číslu Prolegomen (LORMANOVÁ 1970: 118). 
o vytváření a realizaci scénické výpravy“..${ }^{10} \mathrm{~V}$ Kouřilově pojetí je scénografie vědou (či vědeckou disciplínou). Toto Kouřilem stále častěji zdůrazňované tvrzení se postupně, hlavně v sedmdesátých letech, stalo jakýmsi mottem jeho práce a promítlo se do směřování Scénografického ústavu.

Kouřil sice původně vnímal scénografii jako jednu z dílčích disciplín či odvětví divadelní vědy, ${ }^{11}$ avšak později ji začal protežovat jako disciplínu dominantní. Tuto pozoruhodnou skutečnost lze jistě přičítat jeho stále hlubšímu zaujetí scénografickou problematikou, nicméně je také možné soudit, že jí toto privilegium začal proklamativně přisuzovat i z jiných důvodů. Lze mezi ně počítat nejen osobní, ale především politické ambice, které měly praktický rozměr v obavě ze ztráty „moci“ a postavení. Naplnění této obavy, k němuž ostatně později skutečně došlo, by znamenalo nejen osobní ztrátu Kouřila samotného, nýbrž i dalších odborníků, jejichž práci Scénografický ústav zaštitoval - tedy i těch (z hlediska tehdejšího politického režimu hodnocených jako) problematických, jimž např́iklad dle slov Jiřiny Telcové ${ }^{12}$ právě pod zmíněnou záštitou Kouřil umožnil odborné působení. Zřejmě i proto tedy Kouřil až do konce existence Scénografického ústavu hájil takto privilegované postavení scénografie, které dokonce přesahovalo hranice divadelní problematiky. Jak je rovněž patrné z Kouřilových studií i publikačních počinů, které měl na starosti, ambice a velkolepé vize tohoto pojetí scénografie sahaly velmi široce do oblastí historie a teorie divadla i za jejich hranice do sféry dějin či teorie kultury a společnosti. V roce 1972 Kouřil napsal:

[...] scénografie (v ní divadelní technika a technologie) je oborem, který má pro celou kulturu a její technický rozvoj klíčový význam; principy řešení, zásady a další lze aplikovat do velké řady dalších oborů kultury [...]. To má pro metodu práce v naší oblasti velký význam, protože se věci „divadelní dají aplikovat do dalších oborů [...] a to s sebou nese nejen ekonomický, ale též unifikační (a s ním pak typizační a standardizační) význam a přispívá k integraci kulturních a kulturně výchovných činností. (KOUŘIL 1972: 66)

\section{Strukturalistický přístup v teoretickém díle Miroslava Kouřila}

V souvislosti se strukturalismem Pražské školy je zcela zásadní skutečnost, že se autoři Prolegomen Scénografické encyklopedie již v prvním čísle z roku 1970 přihlásili ke strukturalistické metodě - jednak explicitně v textu Jarmily Lormanové (LORMANOVÁ 1970: 118), dále v samotném způsobu zpracování příspěvků obsažených nejen v prvním čísle, jednak zařazováním statí strukturalistických autorů (včetně již zmíněného Jana Mukařovského). Uplatňování strukturalistického přístupu a jeho vývoj lze opět sledovat i v Kouřilově vlastní písemné (tj. nejen té publikované) činnosti v oblasti teorie scéno-

10 (KOUǨIL 1970b: 21), srov. (KOUǨIL 1970a: 43).

11 Kouřil se věnoval i pedagogické činnosti. Působil např. na Univerzitě Karlově - od roku 1962 i v období po zrušení Scénografického ústavu. Přednášel tam do roku 1980, a jistou dobu dokonce zastával funkci vedoucího Katedry divadelní vědy.

12 Informace z osobního rozhovoru Š. Havlíčkové Kysové s Jiřinou Telcovou ze dne 28. 8. 2012. 
grafie, a to během zhruba třicetiletého období, od poloviny čtyřicátých let přibližně do poloviny let sedmdesátých.

Kouřilovo teoretické dílo lze obecně vnímat jako příspěvek k dědictví Pražské školy. Proto mezi nejdůležitější otázky, které je třeba si v této souvislosti klást, patř́i problematika míry možnosti identifikace strukturalistického přístupu a s ním spojeného užívání strukturalistické terminologie, otázka Kouřilova způsobu uplatňování strukturalistické metody, zejména v oblasti analýzy scénografie a divadelního prostoru atd. Rovněž je důležité se ptát, zda a jak se strukturalistická metoda a argumentace v Kouřilově rozsáhlém teoretickém díle proměnily v průběhu let.

Odpověd' na tyto otázky lze najít ve srovnání dvou Kouřilových zásadních teoretických prací - Divadelního prostoru, který považujeme nejen pro dobu jeho vzniku (1945) za dílo nejtěsněji/nejvíce následující český divadelní strukturalismus, a „opusu magnum“, Základů teoretické scénografie, vznikajících v šedesátých a sedmdesátých letech.

\section{Divadelní prostor}

Ve své nepř́liš rozsáhlé studii z roku 1945 se Miroslav Kouřil snažil uplatnit - v duchu tehdy stále rezonujícího ovzduší strukturalismu - strukturalistickou metodu. Činil tak při pokusu teoreticky uchopit a vyložit podstatu divadelního prostoru a počínal si značně systematicky. Jeho text zahrnuje ve strukturalistickém diskurzu obecně zavedené strukturalistické termíny a kategorie. Najdeme v něm např́íklad termíny, jako jsou struktura, složka, znak, systém, funkce, forma atd. Vzhledem ke skutečnosti, že se v této práci Kouřil pokusil ozřejmit scénografické pojmy a vzájemné vztahy mezi nimi, lze ji považovat za příspěvek ke strukturalistickému bádání o divadle v oblasti scénografie a teorie scénografie.

Kouřil se zabývá ponejvíce vztahem mezi divadelním a dramatickým prostorem. Dle jeho tvrzení je divadelni prostor syntézou prostoru hlediště a jevištního prostoru, přičemž $d i$ vadelni prostor je kvalitativně podřízen prostoru dramatickému (KOUŘIL 1945: 35). Dále upozorňuje, že sice můžeme - teoreticky - pozorovat či zkoumat „odděleně“ divadelni prostor, ale nesmíme při tom zapomínat na skutečnost, že jde pouze o ,jeden pól syntézy“, jednu ze sil „složité souhry a bohaté struktury“, kterou nelze „vyjmout bez poškození celku“. „Základní znak divadelního prostoru je dán jeho uspořádáním, je charakterisován poměrem hlediště a jeviště." (35) Kouřil dále definuje divadelni prostor také jako neoddělitelnou statickou složkou dramatického prostoru (41) a tvrdí, že divadelní prostor není „něco svébytně samostatného, ale jen jedna síla v složité struktuře“ (41). Když hovoří o prostorové složce divadla, odmítá ji pojímat staticky (23).

Dramatický prostor charakterizuje Kouřil jako současně působící scénu, hlediště s diváky, akci dramatických postav, světlo a zvuk. „Je to divadelní prostor naplněný děním dramatického díla, nikoliv však ještě dramatickým životem a časem.“ (35) Hovoří také o jeho dynamické podobě a o skutečnosti, že se kromě jiných kvalit vyznačuje tím, že je naplněn dramatickým životem a časem (41). Nutno podotknout, že Kouřil ve své studii používá pojem dramatické dílo ve smyslu pojetí Otakara Zicha. 
Zřejmě nejvíce je Kouřilova vědomá snaha o uplatňování strukturalistické metody patrná v pasážích, které se zabývají samotnou podstatou divadla, již nazývá přímo „strukturální“, a hierarchií jednotlivých složek. Strukturální podstatu divadla Kouřil vymezuje principem syntézy - syntézy umění. Žádná ze složek, které tuto strukturu tvoří, by neměla být ostatním složkám nadřazená, ani by si všechny neměly být „mechanicky mezi sebou absolutně“ rovny. „Složitost vztahů a proměn nedovoluje nic samoúčelně nadřad’ovat; důraz, který je v určitém okamžiku dramatického času položen na určitou složku díla, neopravňuje k požadování prvenství, poněvadž v okamžiku

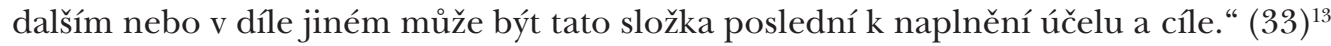
Vysvětlení pojmu složek dramatického díla se věnuje podrobněji na příkladu rozboru Maeterlinckovy hry Alladina a Palomid. ${ }^{14}$ Vyjmenovává konkrétní složky dramatického dila - tj. složku: dramatickou, hereckou, režijní, výtvarnou, hudební, literární a taneční (33). Každá složka divadla chápaného jako syntéza musí mít nějaký vztah k tzv. „účelu“ (42), který ovšem Kouřil bohužel nespecifikuje přiliš jasně. Každá složka má dle Kouřila vztah ke každé jiné složce a při rozboru dramatického díla musí být brány v úvahu všechny tyto vztahy mezi nimi (51). Na zmíněném příkladu inscenace Maeterlinckovy hry Kouřil demonstruje nadřazenost/dominanci jedné ze složek v určitém momentě inscenace:

Burianova koncepce přidržela se rozdělení dramatu na pět oddílů; rozebíráme-li podrobněji, tedy byl první díl charakterisován převážně výtvarnou složkou (sklobetonová stěna, dramatické postavy, hedvábný koberec) již proto, že vstupní text potřebuje takového vyvážení. Výstupy druhého dílu a první výstup tř̌etího aktu charakterisovala složka dramatická (herecká a režijní), aby v druhém a třetím výstupu třetího aktu byla podepřena složkou výtvarnou k znásobenému účinu (na př́ílad dialog Alladiny a Palomida u torsa zakrytého černou krajkou a výstup Astoleny, Ablamora a sester Palomidových v křesle u zelené plastiky sedící ženy); ve čtvrtém a v první polovině pátého aktu opět dominuje složka dramatická (zejména v básnickém dialogu Alladina a Palomida v civilním prostředí t. zv. zkušebny) a v závěru pátého aktu již připomenutý protiklad výtvarné a herecké složky. Avšak i menší celky můžeme obdobně rozebrat [...]. (KOUŘIL 1945: 32)

Podobně je Kouřilův výklad veden a formulován v celém spise. Kouřil užívá strukturalistický pojmový aparát, aniž by však jednotlivé koncepty rozvíjel či reflektoval. Jeho uchopení pojmů a zacházení s nimi se mnohdy jeví až jako mechanické. Za hlavní princip i sdělení jeho studie lze nejspíše považovat tvrzení, že struktura či struktury, zejména struktura divadla a divadelního prostoru, je složitá (komplexní) a že vztahy mezi jejich jednotlivými prvky jsou velmi důležité. Další problematickou stránkou pojednání je skutečnost, že ač jsou jednotlivé pojmy Kouřilem puntičkářsky definovány a neustále usouvstažňovány v rámci textu studie, jejich podstata a funkční principy vztahů mezi nimi nejsou dostatečně ozřejměny. Některá zásadní témata jsou dokonce jen zmíněna

13 Zkoumání dramatických děl by dle Kouřila mělo vést k „poznání složité souvislosti jevů, které dramatické dílo tvoříi" (33).

14 K podpoře svých tvrzení Kouřil zpravidla užívá př́íklady inscenací Divadla D. 
a nadále ponechána bez vysvětlujícího komentáře. Např́klad když uvádí skutečnost, že kvantitativní poměr složek je sic! „proměnlivý“ (KOUŘIL 1945: 32).

\section{Základy teoretické scénografie}

Způsob užití strukturalistického přístupu jako metody v Kouřilově rozsáhlém (a plně nerealizovaném) projektu, který následoval více než dvacet let po publikování Divadelního prostoru, se jeví jako poněkud nekonzistentní. V textu je stále patrné povědomí o zichovském pojetí divadla, zacházení s tradičně strukturalistickými pojmy s naprostou samozřejmostí jako s teoretickými konstantami, tedy vědomá návaznost na práce Pražské školy. To vše je užito v rámci Kouřilova úsilí prosadit a obhájit scénografii (či teorii scénografie) jako vědeckou disciplínu. V této souvislosti vznášel požadavek objektivity (KOUŘIL 1966: 40). Je pozoruhodné, že Kouřil nepřisuzoval vědecké kvality pouze scénografii jako teoretické disciplíně, ale hovořil o nich i v souvislosti s divadlem samotným, tj. divadlem jako uměleckým druhem. Zmiňoval dokonce snahu či potřebu o zvědečtění divadelního umění v kontextu vývoje dějin divadla. V kapitole „Prostorová struktura" tak například tvrdí:

[...] hnutí které dnes jasně historicky vidíme jako velkou reformátorskou vlnu scénografie světovou divadelní avantgardu (1917-1941), se stalo kolébkou současné (1966) scénografie na celém světě. Proto dnes je vhodné mluvit o experimentaci v divadle, protože pohnutky - formálně třeba velmi příbuzné a podobné - vzniku dnešních inscenací tkví ve snaze o zvědečtění divadelního umění; jde ovšem o synthesu umění s vědou v takové míře, aby byly zachovány estetické, tvůrčí, inspirativní a emotivní hodnoty divadla a v něm i scénografie, poněvadž se v objektivním poznání zákonitostí divadelního umění a scénografie pokročilo značně kupředu oproti dobám avantgardy. (KOUŘIL 1966: 40)

Experimentu v divadelní praxi tedy rovněž přisuzuje vědecký rozměr. Jeho úvahy však mnohdy postrádají jasnou pointu, což lze snad přičítat skutečnosti, že jsou mnohdy vedeny v nepublikovaném rukopise. Základy teoretické scénografie se na první pohled obecně jeví jako strukturalistické pojednání, ale podrobnější studium jejich obsahu už pro tuto charakteristiku nehovoří, alespoň ne z hlediska konzistentnosti obsahu. Obecně lze říci, že se jedná o zpracování dějin divadla z perspektivy scénografie. Kouřil často cituje či parafrázuje řadu převážně teatrologických prací, aby popsal jednotlivé pojmy či události. Jeho argumentace však nezřídka postrádá jasný směr a někdy nelze zcela jasně sledovat její logiku. Při pokusu sjednotit různé myšlenky týkající se scénografie a vytvořit z nich jednotnou teorii, jež by objímala veškerou (nejen) scénografickou problematiku, se Kouřil uchyluje k vytváření zjednodušujících definic či tvrzení. Naopak zřídka se zabývá skutečností, jak věci fungují, v jakém jsou vztahu či jak se tyto vztahy či funkce proměňují. Formulace se stále častěji podobají frázím, výčty a klasifikace se velmi vzdalují funkčnímu přístupu, jenž lze najít v pracích Kouřilových strukturalistických předchůdců. Postupně se Kouřil ve svých textech spíše přibližuje způsobu uvažování 
a vyjadřování, které bylo v souladu s „myšlenkami“ podporovanými totalitním režimem tehdejšího Československa, tedy Československa v období tzv. normalizace.

Avšak i Kouřilovy publikované práce se mohou jevit, ač méně často, jako problematické především z hlediska záměru a obsahu svého sdělení. Strukturalistické pojmy, o něž se Kouřilův výklad opírá, pomáhají čtenáři v širším kontextu českého strukturalistického myšlení o divadle pochopit strukturu scénografického a divadelního prostoru. Kouřil dokázal věcně aplikovat strukturalistickou terminologii, a zejména Zichovo pojetí divadelního umění v oblasti scénografie, čímž jistě ve své době přispěl k rozvoji detailnějšího vhledu do problematiky uvažování o scénografii a divadelním prostoru obecně. Jeho přínos ke strukturalistické metodě však lze vnímat ve srovnání s prací jiných teoretiků divadla (např. Jiřriho Veltruského, který také rozvíjel své úvahy v duchu strukturalismu i v druhé polovině 20. stol.) jako méně podnětné pro další rozvoj v oblasti (nejen strukturalistické) teorie divadla.

\section{Závěr}

Ačkoliv jsme dospěli ke konstatování, že přínos aplikování strukturalistické metody Miroslava Kouřila v jeho vlastních teoretických pracích nelze považovat vzhledem k dalšímu vývoji v oblasti teorie divadla (či přímo rozvoji strukturalistické metody) za nijak formativní či zcela zásadní, nelze toto tvrdit o ostatních oblastech jeho práce. Kromě nepopiratelného př́nosu k meziválečné inscenační praxi je třeba zdůraznit jeho počiny kulturně a divadelně organizačního rázu - včetně jeho výše zmíněných aktivit v rámci Scénografické laboratoře, Scénografického ústavu a obzvláště v péči o kolektivní publikační počiny, které daleko přesáhly oblast problematiky scénografie a jsou dodnes užitečnými dokumenty.

Jiří Kolařík ve svém článku pro Acta scaenographica z roku 1970 napsal:

Za Scénografickým ústavem a jeho zakladatelem a stálým inspirátorem Ing. arch. Miroslavem Kouřilem stojí veliký kus práce, jež byla vykonána společným úsilím všech pracovníků ústavu, a jež se uskutečňovala často v obtížných podmínkách a s krajním vypětím sil. Mnoho bylo už uděláno a mnoho - jak napovídají perspektivní plány pro př̌šstí léta - zbývá ještě udělat. Je třeba si přát, aby ani v budoucnu pracovníky ústavu neopustilo úsilí o progresivitu, které nedovolí setrvat v uspokojení a vede tvořivou mysl stále dál. (KOLAŘíK 1970: 3)

Těžko říci, zda šlo o skutečně míněná slova chvály, nebo jen o době poplatné fráze. Domníváme se však, že Kolaříkova slova korespondují s dojmem, který lze z dnešní perspektivy získat ze studia dostupných relevantních materiálů. Ostatně o organizačních schopnostech, entuziasmu i „dobrém úmyslu“ v Kouřilově činnosti hovořila i ve zmíněném rozhovoru jeho někdejší spolupracovnice Jiřina Telcová. Jiří Kolařík shrnoval dosavadní působení Scénografické laboratoře a Scénografického ústavu a vyslovil své přání dalších pracovních úspěchů zaměstnancům v čele s Miroslavem Kouřilem v roce, 
kdy vyšel teprve první díl Prolegomen Scénografické encyklopedie. Tedy vykonáno bylo skutečně ještě mnoho, jak se může i dnes kdokoli přesvědčit, avšak k naplnění zřejmě největší ambice - vzniku Scénografické encyklopedie - již nedošlo.

\section{Bibliografie}

FURTENBACH, Josef. 1944. Prospectiva. Knihovna divadelního prostoru [Library of theatre space], sv. [vol.] 1. Praha: Ústav pro učebné pomůcky průmyslových a odborných škol, 1944.

GROSSMAN, Jan. 1959. Divadelní úlohy filmu [Theatrical Aspects of Film]. Divadlo 10 (1959): 417-440.

HAVLÍČKOVÁ KYSOVÁ, Šárka. 2011. A Journey into Theatrical Space: The Project of the Scenographic Encyclopaedia and its Prolegomena. Theatralia 14 (2011): 1: 244-253.

HAVLÍČKOVÁ KYSOVÁ, Šárka. 2012. Rozhovor s Jiřinou Telcovou o její spolupráci s Miroslavem Kouřilem a aktivitách Scénografického ústavu [Interview with Jiřina Telcová about her collaboration with Miroslav Kouřil and activities of the Scenographic Institute]. 28. 8. 2012. Nahrávka uložena v soukromém archivu autorky [Recording in possession of the author].

HAVLÍČKOVÁ KYSOVÁ, Šárka a Barbora DIEGO RIVERA PŘÍHODOVÁ. 2013. Miroslav Kouřil's Scenographic Theory: Establishing a New Scientific Discipline in the Totalitarian Regime. In Re-Routing Performance, Barcelona, mezinárodní konference [International conference] FIRT/IFTR, 2013.

HAVLÍČKOVÁ KYSOVÁ, Šárka a Barbora DIEGO RIVERA PŘíHODOVÁ. 2014. Archaeology of Concepts and Ambitions: Performing Structuralism through the Field of Scenography (Czechoslovakia, 1970s). Theatralia 17 (2014) 2: 111-121.

HILMERA, Jiří. 1962. Pět let činnosti scénografické laboratoře [Five Years of the Scenographic Laboratory]. Acta scaenographica, svazek [volume] 66 (1962): 2: 21-23.

HILMERA, Jiří. 1970. Co je scénografie? [What Is Scenography?] In Miroslav Kouřil. Prolegomena Scénografické encyklopedie č. [vol.] 1. Praha: Scénografický ústav, 1970: 39-42.

HUML, Václav. 2010. Rozhovor s architektem Daliborem Štysem [Interview with an architect Dalibor Štys]. [datováno 16. 9. 2010]. Dostupné z World Wide Web < http://www.theatre-architecture.eu/cs/rozhovory/rozhovor-s-architektem-daliborem-stysem.html> [citováno dne 17. 11. 2015].

KAZDA, Jaromír. 1973. Braunův Kuks (Pokus o teatrologický rozbor) [Sculptures in Kuks by Matyáš Braun (An Attempt at a Theatrological Analysis)]. In Miroslav Kouřil. Prolegomena Scénografické encyklopedie č. [vol.] 16. Praha: Scénografický ústav, 1973: 80-85.

KOLAŘíK, Jiří. 1967. 1957-1967. 10 let Scénografického ústavu [Ten Years of the Scenographic Institute]. Acta scaenographica 8 (1967): 1: 1-3.

KOUŘIL, Miroslav. 1945. Divadelni prostor [Theatrical Space]. Praha: Ústav pro učební pomůcky průmyslových a odborných škol, 1945.

KOUŘIL, Miroslav. 1955. O malém jevišti [Small Theatre Stage]. Praha: Orbis, 1955.

KOUŘIL, Miroslav. 1966. Základy teoretické scénografie III. [rukopis] [Basics of the Theory of Stage Design III, a manuscript]. Praha: Scénografický ústav, 1966. 
KOUŘIL, Miroslav. 1949. Základy nové práce československého divadelnictvi [The Foundations of the New Czechoslovak Theatre]. 1949.

KOUŘIL, Miroslav. 1950. Úkoly československého divadelnictvi [The Mission of the Czechoslovak Theatre]. Praha, 1950.

KOUŘIL, Miroslav. 1970. Prolegomena Scénografické encyklopedie, č. [vol.] 1. Praha: Scénografický ústav, 1970.

KOUŘIL, Miroslav. 1970a. Pokus o definici I [An Attempt at a Definition I]. In Miroslav Kouřil. Prolegomena Scénografické encyklopedie č. [vol.] 1. Praha: Scénografický ústav, 1970: 43-47.

KOUŘIL, Miroslav. 1970b. Základy teoretické scénografie. Úvodní úvahy. Část 1 [Basics of the Theory of Stage Design. Introductory Observations, vol. 1]. Praha: Scénografický ústav, 1970.

KOUŘIL, Miroslav. 1971. Prolegomena Scénografické encyklopedie. Díl 2 [Prolegomena of the Scenographic Encyclopaedia, vol. 2]. Praha: Scénografický ústav, 1971.

KOUŘIL, Miroslav. 1972. Patnáct let Scénografického ústavu [Fifteen Years of the Scenographic Institute]. Interscaena '72/Acta Scaenographica 4 (1972): 2: 65-66.

KOUŘIL, Miroslav. 1973. Prolegomena Scénografické encyklopedie. Díl 20 [Prolegomena of the Scenographic Encyclopaedia, vol. 20]. Praha: Scénografický ústav, 1973.

KOWZAN, Tadeusz. 1973. Znak v divadle [A Sign in Theatre]. In Miroslav Kouřil. Prolegomena Scénografické encyklopedie č. [vol.] 18. Praha: Scénografický ústav, 1973: 7-22.

LORMANOVÁ, Jarmila. 1970. Koncepce Scénografické encyklopedie [The Conception of the Scenographic Encyclopaedia]. In Miroslav Kouřil. Prolegomena Scénografické encyklopedie č. [vol.] 1. Praha: Scénografický ústav, 1970.

LUKÁČOVÁ, Kateřina. 2016. Úkoly Scénografického ústavu [The Activities of the Czech Scenographic Institute]. Theatralia 19 (2016): 1: 159-180.

RAUCHOVÁ, Jitka. 2011. Spoutané divadlo: Jindřich Honzl, Jiř́ Frejka a Emil František Burian v systému kulturni politiky (1945-1959) [Theatre Bound: Jindřich Honl, Jiří Frejka and Emil František Burian in the Concept of Cultural Policy (1945-1959)]. České Budějovice: Společnost pro kulturní dějiny, 2011.

SPURNÁ, Helena. 2004. Theatergraph. In Petr Pavlovský a kol. Základni pojmy divadla. Teatrologický slovnik [Basic Theatre Terminology. A Theatre Encyclopaedia]. Praha: Libri, 2004: 272-273.

SRBA, Bořivoj. 1971. Poetické divadlo E. F. Buriana [Poetic Theatre of E. F. Burian]. Praha: Státní pedagogické nakladatelství, 1971.

SRBA, Bořivoj. 2006. Řě̌i světla [The Language of the Light]. Brno: JAMU, 2006.

TELCOVÁ, Jiřina. 1970. Co je scénografie? [What Is Scenography?]. In Miroslav Kouřil. Prolegomena Scénografické encyklopedie č. [vol.] 1. Praha: Scénografický ústav, 1970: 48-51.

VEBER, Václav. 1971. 60 let Miroslava Kouřila [The 60th Anniversary of Miroslav Kouřil]. Praha: Scénografický ústav, 1971.

VITRUVIUS, Markus a Julius POLLUX. 1944. Antické divadlo [The Ancient Greek and Roman Theatre]. Překl. [transl.] Jaroslav Pokorný. Knihovna divadelního prostoru [Library of theatre space], sv. [vol.] 5. Praha: Ústav pro učebné pomůcky průmyslových a odborných škol, 1944. 


\section{Summary}

\section{Miroslav Kouřil and His Approach to Structuralism as a Method and Programme}

The study explores theoretical works and managing activities of Czech set-designer Miroslav Kouřil (1911-1984). First part is devoted to two crucial periods in Kouřil's professional life: his career of a stage designer, and the following involvement in theoretical reception of theatre and practical organization of theatre life in the then Czechoslovakia. In the second part, attention is drawn to Kouřil's presidency over the Czech Scenographic Institute, and to the project of the Encyclopaedia of the Set Design managed by him. In the third part, the author concerns with Kouřil's theoretical works, especially the way in which he used structuralist methodology to analyse theatre productions.

\section{Klíčová slova}

Miroslav Kouřil, Scénografický ústav, Scénografická laboratoř, strukturalismus, divadlo, Prolegomena Scénografické encyklopedie

\section{Keywords}

Miroslav Kouřil, The Czech Scenographic Institute, The Scenographic Laboratory, structuralism, theatre, Prolegomena to the Encyclopaedia of Theatre

DOI: $10.5817 /$ TY2016-1-7

Mgr. Šárka Havlíčková Kysová, Ph.D. vystudovala teorii a dějiny divadla a český jazyk a literaturu na Masarykově univerzitě v Brně (ČR). V roce 2010 absolvovala doktorské studium divadelní vědy na Filozofické fakultě MU disertační prací s názvem Hastábhinaja. Gesta rukou v tradičním divadelním uměni Indie. V minulosti se ve své přednáškové i výzkumné činnosti zabývala ponejvíce asijským divadlem - především tradičním indickým divadlem kúdijáttam. V současné době mezi její hlavní pedagogické i výzkumné zájmy patří teorie divadla, zejména kognitivní přístup, a problematika inscenování opery.

V letech 2011-2015 se na Katedře divadelních studií FF MU podílela na řešení grantového projektu „Český divadelní strukturalismus: souvislosti a potenciál“ (GAČR), od roku 2012 do roku 2014 pracovala na projektu „Inovace uměnovědných studijních oborů na Filozofické fakultě MU“ (OPVK). Od roku 2015 je hlavní řešitelkou výzkumného grantového projektu (GAČR) „Generace Miloše Wasserbauera a progresivní dramaturgie v opeře Státního divadla v Brně“. Kontakt: sarka.havlickova@mail.muni.cz.

Mgr. Šárka Havlíčková Kysová, Ph.D. received her M.A. in theatre history and theory, and in Czech language and literature from Masaryk University in Brno (Czech Republic). She continued her graduate studies in theatre and received her $\mathrm{PhD}$ in 2010 (doctoral thesis Hastabhinaya. Hand gestures in traditional theatre art of India). She has focused in her research and teaching on Asian 
theatre, the traditional Indian theatre genre koodiyattom in particular, recently turning attention also to theatre theory, especially its cognitive strand, and opera staging.

From 2008 till 2009 she worked as a curator of collections of set designs in the Department of Theatre History, Moravian Museum; from 2009 till 2012 she taught theatre theory at the Department of Theatre, Film and Media Studies, Palacký University in Olomouc (CZ). From 2011 till 2015 she has been employed at the Department of Theatre Studies at Masaryk University on a research grant project "Czech Theatre Structuralism: Context and Potential" supported by the Czech Science Foundation (GAČR); from 2012 till 2014 she collaborated on the European grant project "Innovation of the art and culture study programmes at the Faculty of Arts, Masaryk University" (OPVK). Since 2015, she has been managing a research grant project "The Generation of Miloš Wasserbauer and the progressive opera dramaturgy in the State Theatre in Brno" (GAČR). Email: sarka.havlickova@mail.muni.cz. 